\title{
Death is Swallowed Up in Victory \\ Scenes of Death in Early Christian Art and the Emergence of Crucifixion Iconography
}

\section{FELICITY HARLEY MCGOWAN}

UNIVERSITY OF MELBOURNE

In Jerusalem in the first century $\mathrm{AD}$, a Jewish man named Jesus was condemned under Roman law to death by crucifixion-charged with claiming to be King of the Jews. ${ }^{1}$ The earliest accounts of the death are in the four canonical Christian gospels; ${ }^{2}$ yet the fact of Jesus' crucifixion is also well attested in other ancient texts, from the historian Tacitus to the Greek satirist Lucian and the Jewish historian Josephus. Underlying a central tenet of the Christian faith, the event came to occupy a preeminent position in Western Christian culture both as an image and an idea; and, even in the face of rising secularism, the crucifixion of Jesus today remains a universally recognisable death scene. When reconstructing the scene of Jesus' death, artists have had direct recourse to the Gospel accounts for content and inspiration. Yet given that illustrated narratives are seldom merely the visual equivalents of literary texts, it is not surprising to discover that even the first known attempts at depicting this notorious event were not reliant upon those reports alone. ${ }^{3}$

This article examines the Maskell Passion Ivories (Figure 1), which include the earliest surviving visual representation of the crucifixion in a narrative context-that is, the first known image of Jesus on a cross that occurs as part of a 
comprehensive pictorial narration of his arrest, death and resurrection-and some of the artistic and theological issues surrounding the formulation of this image in fifth century Rome. ${ }^{4}$ The discussion of Jesus' crucifixion as it is portrayed on the Maskell Ivories will be set against a brief survey of the way in which death as a subject was generally treated in the earliest Christian art. This survey is critical in appreciating the thematic and iconographic milieu into which the story of Jesus' own death was introduced. The visual context in which the image was viewed will then be described (decorating the exterior sides of a hand-held casket), and followed by an examination of the narrative context into which the image was set (that is, as part of a sequence of images recounting the story of the arrest, death and resurrection of Jesus).

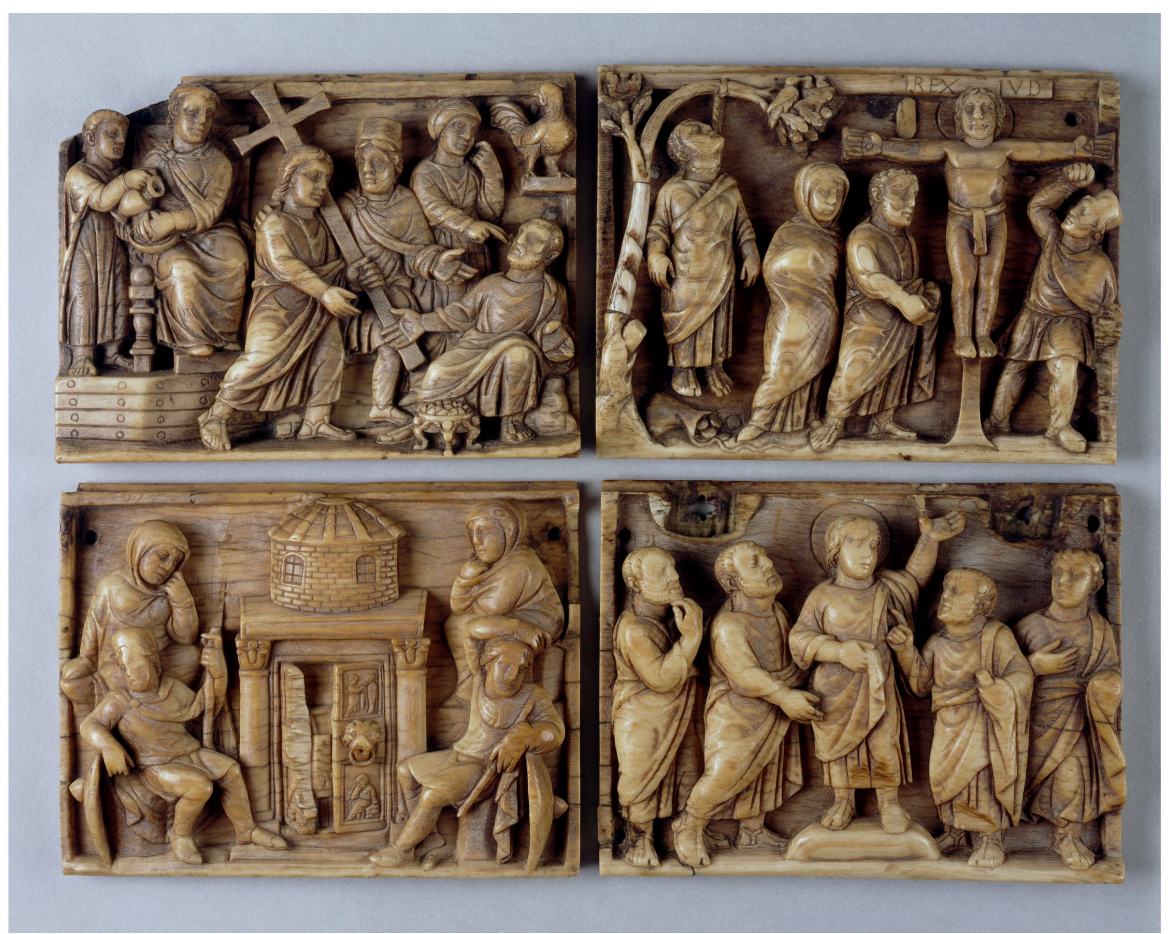

Figure 1: The Maskell Passion Ivories: Four ivory plaques with the Passion and Resurrection of Christ. Ivory, Rome, c. 420-430. Each panel approximately 7.5 × $9.8 \mathrm{~cm}$.

Source: British Museum, Department of Prehistory and Europe, MME 1856.06-23.4-7. From the Maskell collection. Reproduced by courtesy of the Trustees of the British Museum. 
This crucifixion scene will be shown here to preserve vital information about the way in which early Christians experimented with the formulation of a visual language ${ }^{5}$ to suit a particular didactic interest: the power of Jesus in defeating death, and the power of his Church in Rome in particular. This visual language is carefully constructed to communicate with an audience intimately acquainted with the textual descriptions of Jesus' death, conversant with the complexities of Christian theology, as well as familiar with the visual 'tropes' of Graeco-Roman funerary art as they were employed in the private sphere. Probing the components of this language, we find that the appropriation of these 'tropes' in early Christian art facilitated a high degree of innovation and experimentation with the narration of a well-known biblical story, as artists, and clients, constructed a death scene to convey a very particular message. Yet the primary focus of the discussion will be the fundamental interest in power and triumph that the image carried. This interest will be shown to be congruent with the major thematic interest of Christian funerary art in the third and fourth centuries, wherein the fact of death was not principally recalled, but rather, instances of deliverance from death. ${ }^{6}$

The Maskell Crucifixion demonstrates that in the fifth century, this characteristic interest in deliverance from death was taken to a new level-a move that would prove pivotal for the development of Christian art from that time onwards. For in the treatment of death scenes in Christian art after the sixth century, scenes from the Bible, literature detailing the deaths of martyrs, and particularly in the depiction of Jesus' own death, the process by which the deaths occurred was in both private and public artistic contexts increasingly enunciated in the way Romans had once been accustomed to seeing the violent deaths of their enemies conquered in battle. These images were detailed on public monuments in the late Roman period emphasising the horror, the pain and often violence of death. ${ }^{7}$

As part of the narrative illustrated across the Maskell Ivories, the crucifixion scene preserves an iconography that is firmly a product of its time and culture; it can therefore be seen to reflect the way in which contemporary viewers mused not only on the death of the Jewish man Jesus, but also contemplated their own mortality. While the image directly tackles the fact of Jesus' execution, reconstructing events at the scene of his crucifixion in some detail, it uses another death (the suicide of 
Judas) and later events (the Resurrection) to effect a powerful interpretation of the event and thereby underscore a broader reality: Jesus' ultimate defeat of death.

\section{-DEATH IN EARLY CHRISTIAN ART}

By around $200 \mathrm{AD}$, Christians across the Roman Empire had begun to experiment with the making of their own images. ${ }^{8}$ No securely dateable and recognisably Christian art survives from before this date, and archaeological and literary evidence that might furnish a clearer understanding of the origins and nascent development of specifically Christian images (that is, those making direct reference to particular biblical texts or Christian themes) is scarce.

The relatively slow emergence of Christian iconography has traditionally been explained away by the belief that the earliest Christians were (like their Jewish forebears) hostile towards the visual arts. Yet this popularly held theory has been shown to be untenable, with the careful demonstration that the supposed opposition of Christian theologians across the second and third centuries to images has been exaggerated by modern scholars. ${ }^{9}$ With no proof that iconography, apart from its idolatrous abuse, was vehemently rejected by the Church as a whole prior to the late second century, the question of why Christians started making images when they did remains a topic for debate. ${ }^{10}$

Initial experimentation with the creation of images, and thereby the development of a Christian iconographic language, may have involved a range of media commissioned and used by the elite as well as the popular classes ${ }^{11}-$ including fresco, textile, mosaic, sculpture, metal work, engraved gems, engraved glass, ivory, wood and bone carving. However, such objects survive in comparatively small numbers, and most of the art that dates from the first Roman Christian centuries is funereal in nature. With some significant exceptions, it is preserved in two contexts: first, in the painted cycles decorating the walls and ceilings of certain Roman catacombs-the underground burial chambers in which the first Christians, along with pagans and Jews, interred their dead; and second, on the carved marble sarcophagi produced largely in Rome and in which the remains of the deceased were placed. ${ }^{12}$ In this way, the earliest Christian art that survives from before the fourth century is firmly rooted in the Graeco-Roman culture of death. ${ }^{13}$ The visual programs carefully created to decorate the tombs or sarcophagi reveal much about 


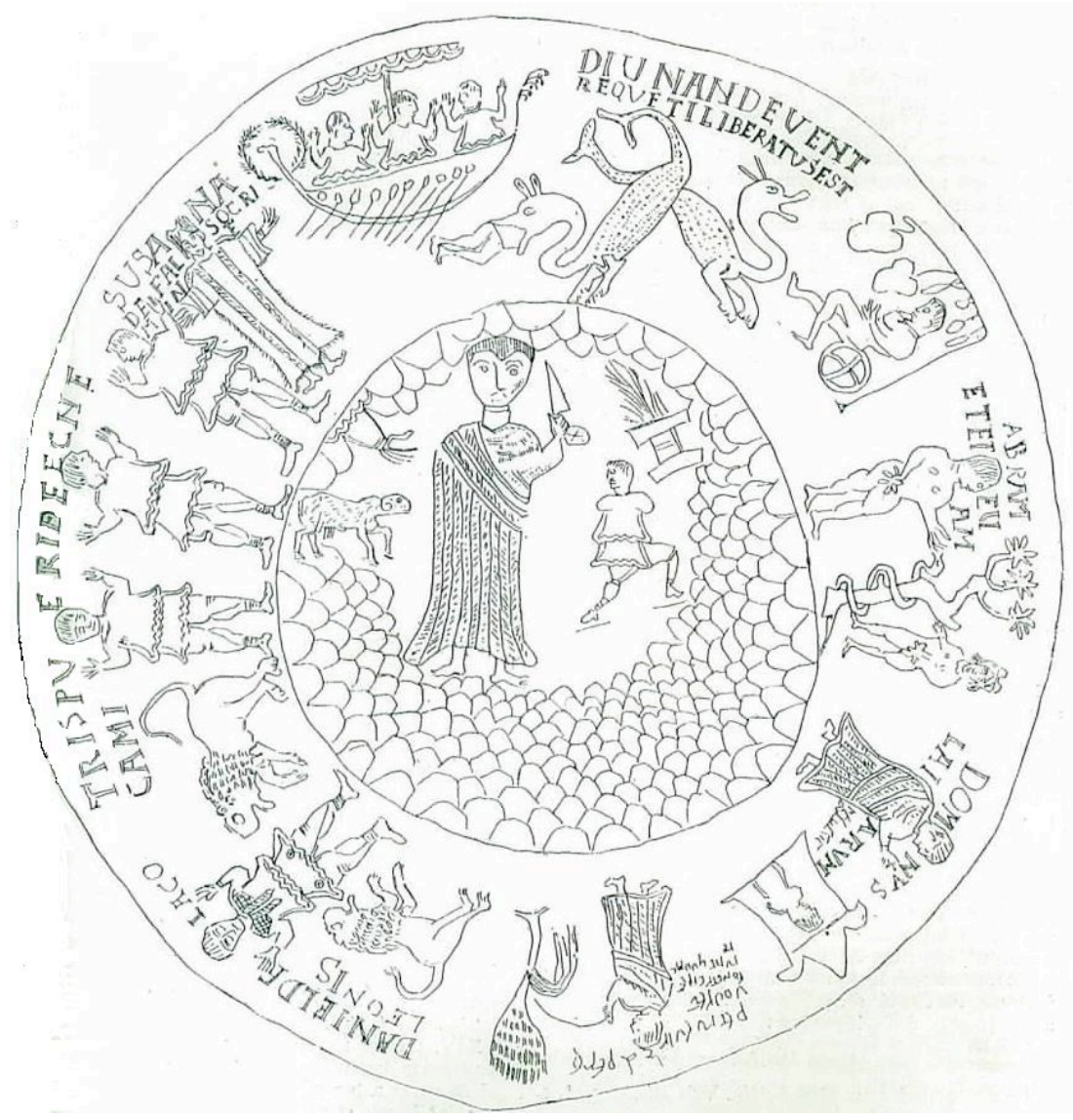

Figure 2. The Podgoritza Bowl: glass, engraved with biblical scenes, fourth century. State Hermitage Museum, Saint Petersburg.

Source: Drawing after E. Le Blant, Étude sur les sarcophages chrétiens antiques de la ville d'Arles, Imprimerie Nationale, Paris, 1878, pl. 35.

the primary concerns of early Christian communities, families and elite individuals in Rome as they dealt with human mortality. Despite the fact that this extant Christian art was connected directly with ritual acts of commemoration and mourning that were an integral and dynamic element of daily life in Rome, ${ }^{14}$ it does not manifest this connection through the actual depiction of such rituals, or through association with the deaths of heroes, as in other Graeco-Roman funerary art. ${ }^{15}$

In the third century and fourth centuries, Christian families and individuals who were wealthy enough to do so decorated the walls and ceilings of rooms (cubicula) within the catacombs. ${ }^{16}$ We find that the subjects chosen for illustration in the pictorial cycles are taken from the Old and New Testaments, but drawn from a 
very small repertoire. The most prominent subjects include Noah and the Ark (Genesis 6-9), Abraham about to sacrifice his son Isaac (Genesis 22:1-24), Jonah and the whale (Jonah 1-3), the three Hebrews in the fiery furnace (Daniel 3), Susannah (Daniel 13) and the prophet Daniel in the lion's den (Daniel 6:5-25, 14:22-42). Each of these stories served as an allusion to personal salvation, the illustration of the protagonist transcending death offering a paradigm of divine deliverance to the mourning family and to the deceased. In the case of Daniel for example, such Church fathers as Clement of Rome (d. 101AD), Origen (b.c. 185-254), and Cyprian of Carthage (b.c. 208), also celebrated the prophet's story as an example of the power of prayer. Thus among the most striking features of these illustrations is their vivid, jubilant quality: the subjects are portrayed as overtly joyful stories, devoid of direct references to death, dying or even mourning. They are visual celebrations as much as reminders that God helps those who trust in Him, and receives the intercessions of those who pray to Him.

These chosen scenes were depicted alongside a stock range of symbols drawn from pagan funerary art that could be adapted to a Christian context, as well as traditional decorative motifs including vine scrolls, garlands and symbols drawn from bucolic landscapes. ${ }^{17}$ The same motifs and stories were carved across the fronts (and sometimes the lids) of the marble sarcophagi in which wealthier Christians could be buried, and on a range of smaller objects, such as terracotta lamps or gemstones worn in finger rings.

In attempting to understand the remarkable consistency with which Christians drew on the same core group of subjects for illustration, an interesting link has been found between the members of this limited repertoire and the contents of a popular early Christian prayer for the dead, the commendatio animae or 'commendation of the soul', which invoked the salvation of biblical figures who were delivered from death by God. Each line of the prayer begins, 'Deliver, Lord, his soul, just as you delivered', before making reference to such Old Testament figures as Elijah, Noah, Abraham, Daniel, Susannah, as well as Peter and Paul. ${ }^{18}$ A fourthcentury glass bowl found at Podgoritza (Montenegro), furnishes a fine example both of the creative use of scenes from this repertoire, and their explicit connection with the commendatio animae (Figure 2). Abraham about to sacrifice his son Isaac is featured prominently in a medallion at the centre of the bowl, and is encircled by a 
frieze of smaller scenes that includes standard representations of the three Hebrews in the fiery furnace, Jonah, Adam and Eve (Genesis 2), Susanna and Daniel. ${ }^{19}$ As Spier has argued, accompanying Latin inscriptions quoting directly from the prayer explicitly tie the pictorial cycle to that prayer. ${ }^{20}$

While the choice of subjects could vary from context to context, the presentation of each particular story was consistent and adhered to a specific iconographic formula. So for instance, to narrate the story of Daniel miraculously being saved from death when thrown to the lions, artists used just three visual components-as showcased on the Podgoritza Bowl: Daniel standing with arms raised in prayer and facing the viewer, flanked by two lions. ${ }^{21}$ In this way, long and involved stories were stripped down to their essential narrative components, their broader theological significance thereby evoked cogently and powerfully for the viewer. As the medley of images arranged on the bowl attests, in the use of abbreviated iconographic types to refer visually to the stories of specific biblical characters delivered from death, it was the rescue of the protagonists and the theme of personal salvation that was primary-the images reflecting the individual's hope of and belief in a new life in the Resurrected Lord. Alongside these images, there was no place for the depiction of the various deaths described in the Old or New Testaments.

One possible third-century exception was the New Testament story of Lazarus of Bethany, who does die and is buried (John 11:1-46). Yet this story is a means of referring to the power of intercessory prayer (Lazarus' sisters having interceded with Jesus on Lazarus' behalf) and divine deliverance. The story does not emphasise the mourning that was such an integral part of the commemoration of death in the ancient Roman world of which Christianity was a part. The Johannine narrative itself certainly portrays Jesus as deeply moved by his friend's death, and even as weeping (John 11.35). However, in art the story is consistently represented in one episode (John 11:38-43): Jesus coming to the tomb and restoring his friend to life, with Lazarus often shown still bound in his burial clothes, standing at the door or walking out of his tomb. Events prior to and including the death are not depicted. Lazarus is never portrayed as a dead figure, and his sisters are not shown lamenting or mourning his death. By recounting the fact of his resurrection therefore, the story 
of Lazarus raised from the dead was thereby a key member of the small corpus of images utilised in the third and fourth centuries, and a highly popular subject.

When in the fourth century additional scenes of 'death' were introduced into the limited repertoire, such newcomers functioned along the same lines as the Lazarus images-showing the protagonist being raised from death, and thereby functioning to assert the broader theme of eternal salvation that remained explicit across this new century. An example is the representation of Jesus raising the daughter of Jairus (Luke 8:52-55). This story is included on an ivory box known as the Brescia Casket, carved probably around 390 in Northern Italy and although small in size (roughly $32 \times 22$ × $25 \mathrm{~cm}$ ), decorated with a complex program of thirtythree biblical stories (Figure 3). ${ }^{22}$ The casket is likely to have had a liturgical function, either as a reliquary or a container for a portion of the consecrated host. As Elsner has pointed out, regardless of its function, it was a container of sanctified matter used in a context of worship rather than burial, ${ }^{23}$ and we might expect a largely changed or diversified core of images within the intricate arrangement of thirty-three scenes. What we find is that the raising of Jairus' daughter appears alongside several of the classic deliverance scenes prominent in third century funerary art, such as Jonah, Daniel, Susanna, the three Hebrews, the healings of both

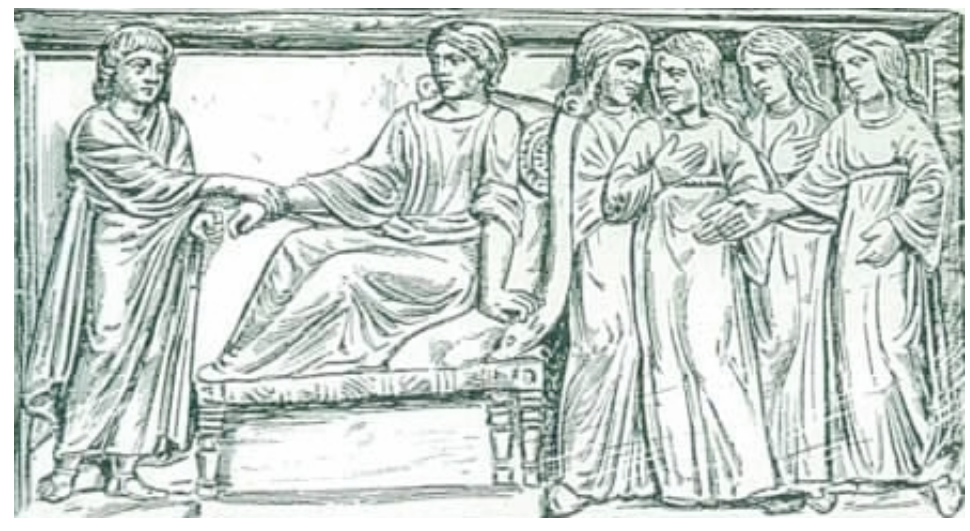

Figure 3: The Brescia Casket, left side (detail: middle register): The Raising of Jairus' daughter. Ivory, Northern Italy (Milan?), late fourth century. Aproximately $32 \mathrm{~cm}$ long, $22 \mathrm{~cm}$ wide, $25 \mathrm{~cm}$ high; Brescia, Museo Civico.

Source: Drawing after F. Cabrol and H. Leclercq, Dictionnaire d'archéologie chrétienne et de liturgie, Letouzey et Ané, Paris, 1907-1953, vol 2, part 1 (1910), fig. 1628, cols. 1153-1154. 
the blind man (at Bethsaida, Mark 8:22-26) and the Woman with the issue of blood (Mark 5:25-34; Matthew 9:18-26; Luke 8:40-56), as well as the raising of Lazarus.

As with the earlier scenes of deliverance, specific iconographic formulae for the representation of these newer subjects were formulated and circulated. Hence the depiction of the raising of Jairus' daughter on the Brescia Casket is iconographically commensurate with depictions on contemporary sarcophagi. Jesus is shown grasping the wrist of Jairus' daughter in the act of healing her, drawing her upright in her bed while the girl's grieving companions stand to the right of this scene. The emotive gestures and dishevelled hair of the companions are familiar from classical art for the depiction of women in distress or grief, and so betray the carver's familiarity with such iconographic conventions. ${ }^{24}$ Yet this is by no means a classical representation of death where expressions of profound grief imbued the story and serve as an end point in a tragic narrative. Transposed into this Christian narrative context, they buttress the significance of a different end point: deliverance from death.

The pictorialised story of Jairus' daughter has been seen to have inspired the depiction of another: the raising of the devout woman Tabitha from the dead (Acts 9:36-42), a subject which appears as one of a medley carved across a series of three ivory reliefs, depicting acts of Jesus' apostles Peter and Paul (Figure 4). ${ }^{25}$ Made in Rome around $430 \mathrm{AD}$, the three rectangular panels each measure $4.2 \times 9.8 \mathrm{~cm}$. The composition seen on the Brescia Casket for Jairus' daughter (Figure 3), with its use of pictorial space to recreate a bedside miracle scene, is repeated with minimal changes. Instead of Jesus, Peter is now shown performing the miracle.

As Kessler has critically observed, by modelling this scene on the developed convention for the depiction of the healing of Jairus' daughter, the carver of the Roman ivory made a firm statement about Peter as heir to Jesus' power and ministry. ${ }^{26}$ For, as a group, these ivories explore the primacy of Peter and Paul in the mission of the church-in the narration of specific events, both canonical and apocryphal, that occurred in their ministry. In addition to the 'death' scene of Tabitha, the series includes an episode in which death is not so much depicted as anticipated. The representation of a man about to hurl a stone at Paul may be a depiction of Acts 14:19, which describes Paul as having been stoned and then dragged out of the city of Lystra, presumed dead. What we find in this series of 


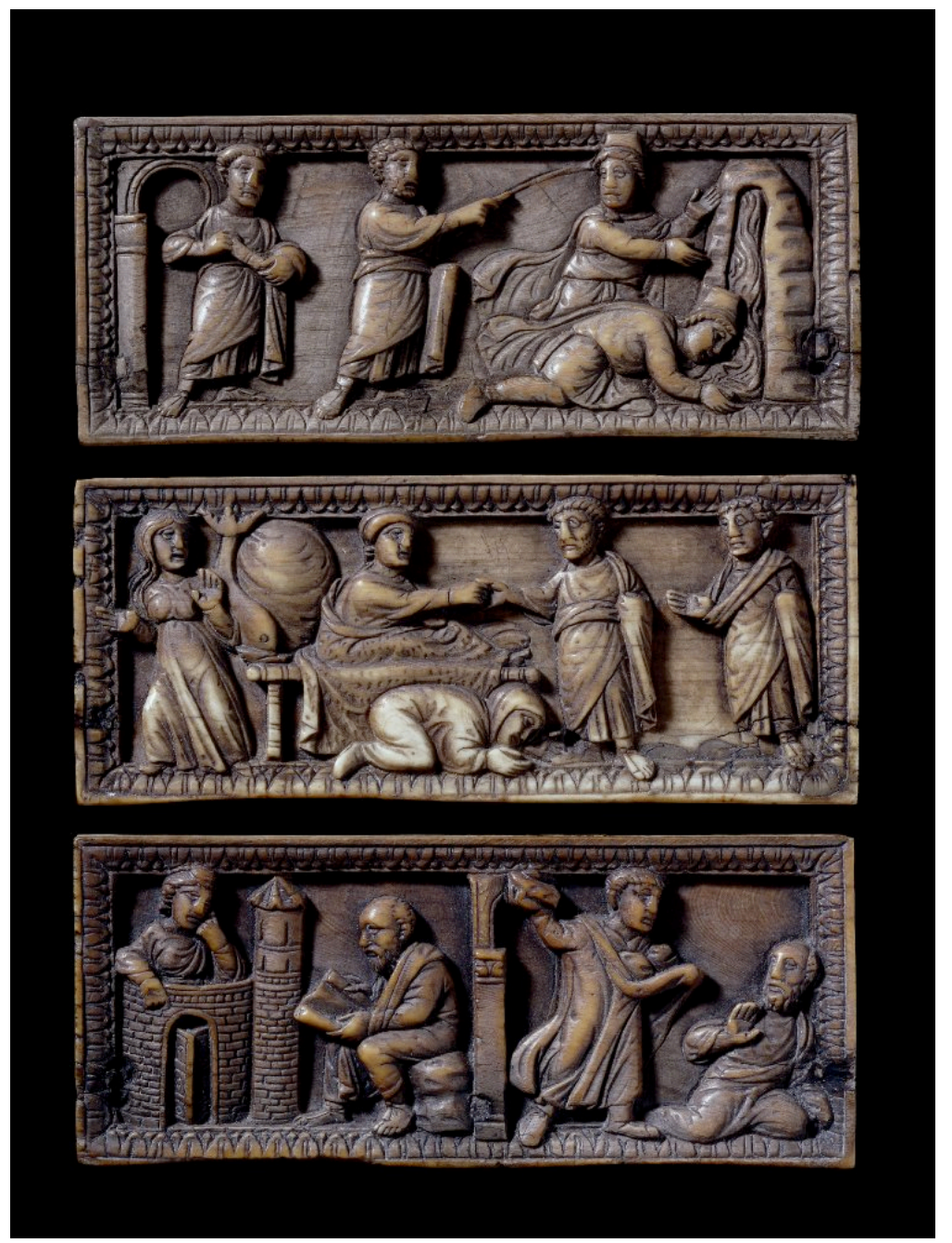

Figure 4: The Apostle Ivories: Three ivory plaques with scenes from the Acts of the Apostles.

Rome, c. 430 . Each panel $4.3 \times 9.8 \mathrm{~cm}$

Source: British Museum, Department of Prehistory and Europe, MME 1856.06-23.8-10. From the Maskell Collection. Reproduced by courtesy of the Trustees of the British Museum.

Roman ivories therefore is evidence of an impetus among artists and their patrons to look to different sources for new Christian stories-in this case, stories from the Acts of the Apostles and from early Christian legend and apocryphal literature, which proffered various subjects that could function effectively in visual narratives both as paradigms of salvation (as the traditional third century corpus did) as well as illustrating key aspects of Christian history. 
Other depictions of death in the fourth century more clearly reflect this shift in Christian narrative art towards the use of post-death scenes, not simply as paradigms of salvation, but as events that teach specific lessons, and about the role of the apostles as Jesus' successors. A fine example occurs in the main, central panel on the back of the Brescia Casket already discussed, where two episodes from the story of Ananias and Sapphira (Acts 5:1-11) are told (Figure 5). According to the account in Acts, Ananias and his wife Sapphira sold a piece of property, but deceived Peter as to how much money they received for it. When Peter confronted Ananias, the man died. Peter then prophesied that the same men who buried Ananias would come for his wife, Sapphira, and carry her to her own burial. In the depiction of this story on the casket, two episodes are shown simultaneously in the same pictorial space. On the left, Peter is depicted sitting in judgement over Sapphira, a bag of money lying between them as a symbol of the couple's betrayal. In the confrontation between the two figures, the imminence of her death is underscored by the action taking place to the right of this episode, where the dead Ananias is being carried away, out of the scene to his burial. ${ }^{27}$ But is he dead? As he is removed, Ananias seems to be turning back to face Sapphira, his right arm stretching upwards as if gesturing, yet his eyes are closed. In what thus seems to be a confliction of narrative detail-Ananias taken to be buried, yet paradoxically exhibiting signs of life-the artist might be seen cleverly to evoke in the one image a time both before and after Ananias' death.

Adjacent to the panel on which this story is played out is another, smaller panel, on which Judas is depicted (Figure 5), having committed suicide by hanging himself from a tree (Matthew 27:3-5). Judas, one of the twelve original apostles, betrayed Jesus for a bribe of thirty pieces of silver (Matthew 26:14) by identifying him with a kiss to arresting soldiers of the High Priest Caiaphas, who then turned Jesus over to Pontius Pilate's soldiers. The Gospel of Matthew records that Judas returned the money to the priests before hanging himself (Matthew 27:3-10). This image very succinctly recalls the broader story of which it is the dénouement. 


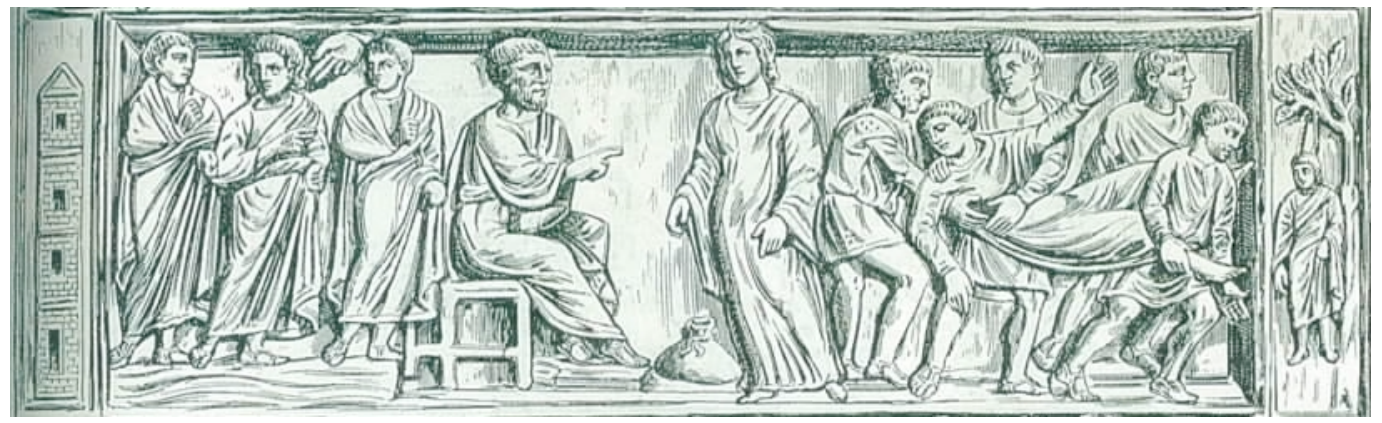

Figure 5: The Brescia Casket, back panel (detail: middle register), The transfiguration (?), Judgement of Aanias and Sapphira, Judas' suicide. Ivory, Northern Italy (Milan ?), late 4th century. Brescia, Museo Civico.

Source: Drawing after F. Cabrol and H. Leclercq, Dictionnaire d'archéologie chrétienne et de liturgie, Letouzey et Ané, Paris, 1907-1953, vol 2, part 1 (1910), fig. 1626, cols 1149-1150.

Collectively, the stories as juxtaposed here represent three stages of death: Sapphira's end is prophesied, the dead-but-gesticulating Ananias is carried off to his death and burial, and Judas is dead beyond doubt. These contrasting 'scenes' of death therefore, can be read as didactic examples concerning evil deeds. ${ }^{28}$ The protagonists are contrasted most implicitly to Peter who serves as the example of a person who made a bad choice (in denying Jesus three times, Luke 22:31-62) but unlike Judas, who killed himself in despair and Ananias and Sapphira, who died, Peter repented and was forgiven.

From this overview it is clear that the earliest representations of (actual, rather than merely potential) deaths in early Christian art were pointed in their focus on actions after the event-specifically, the miracle of a person's restoration to life (as in the cases of Lazarus, and less commonly Tabitha and Jairus' daughter) and the subsequent reaction of the witnesses to that miracle. Such scenes of resurrection articulated a very personal hope of new life after death and, by and large, the reactions of witnesses remained relatively muted in images that survive from across the third century, only developing increasing dynamism and even diversity across the fourth century. By the late fourth and early fifth centuries, early Christian artists were beginning to admit a greater number of 'death' scenes into their repertoire. The surviving imagery suggests that in order to do this they were turning to biblical texts beyond the older emphasis on the Old Testament and the canonical Gospels, 
and now including the Acts of Apostles and other traditions (such as for the ministry of Paul) among favoured subjects.

Bearing this evidence in mind, it should not be surprising when turning to consider how the subject of Jesus' own death was approached in Christian art, to discover two principal things: first, that the subject was seemingly slow to find a suitable niche within the earliest pictorial schemata; second, when it did come to enter (as part of the general expansion of narrative images in fourth and early fifth century and specifically the broader admission of 'death' scenes noted above), the emphasis was firmly on his Jesus' victory over death. So, as a 'death' scene, the subject did not fit readily within the accepted repertoire of scenes with their particular emphasis on deliverance; however, as a scene of triumph, it certainly did.

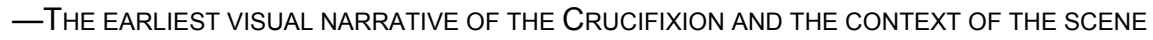

The depiction of Jesus' own death by artists in the fourth and fifth centuries corresponds to the characteristics of the death scenes just discussed. Like the death of Lazarus, that of Jesus is dealt with primarily as a subject that affirms the viewer's hope in resurrection to eternal life, rather than documenting the death itself. Pictorially, this is popularly dealt with in two ways: the risen Jesus is seen either beside the tomb in which he had been buried, or amongst the women in the garden, both options symbolising that he has been raised from the dead. In the later fourth and early fifth centuries, further episodes in the Passion narrative are added to the repertoire of post-resurrection scenes in order to confirm the fact of restoration to life: Christ standing among the apostles and the doubting Thomas, for example. Less common were depictions of Jesus on the cross. Difficult as this subject was, at an immediate level conjuring violence and suffering, a solution was found: Jesus was depicted not dead (with eyes closed) but alive (with eyes open), transcending the moment of his execution.

Judging from extant evidence, it appears that Jesus' death itself was rarely illustrated before the sixth century. There are three surviving engraved gems, a miniature and highly personal visual context where there is little space for accompanying images or symbols, or explicit narrative development. Yet the iconographic emphasis is undoubtedly on Jesus' triumph over death, and so on his 
Resurrection, in that he is shown upright, unaffected by the process of his crucifixion, and accompanied by the twelve apostles. ${ }^{29}$

Alongside further archaeological and literary evidence, the gems attest that some attempts were made as early as the third century to depict Jesus on his cross. ${ }^{30}$ It is not until the fifth century that we have any evidence to indicate that such a depiction was set within a narrative context that attempted to recreate the historical scene of the death. The earliest extant image that begins to do so is on one of four ivory panels carved in Rome sometime between 420 and $430 \mathrm{AD}$, and now known collectively as the Maskell Passion Ivories (Figure 1). ${ }^{31}$ Together, they depict seven episodes from the narrative of Jesus' death and resurrection, ordered in historical sequence. In the episode of the crucifixion, Jesus is shown nailed to his cross in the presence of his mother, Saint John, and a soldier who pierces his side with a lance. Yet he is not dead; Jesus' eyes are open, and his muscular semi-naked body is contrasted sharply with another, that of Judas, whose lifeless limbs and closed eyes leave the viewer in no doubt this clothed figure hanging from a tree is dead.

In turning to focus on this representation, several things must be said about the object of which it was a part. In form and carving style, the panels have been aligned with the ivory diptychs commissioned in the early fifth century by the senatorial classes to commemorate both private events (such as marriages) and public (primarily, appointment to the position of consul). ${ }^{32}$ Though now separated, the four panels were originally mounted on the sides of a square casket with a hinged lid, now missing along with the base of the box. This purpose is made certain by the uniform size of each panel, approximately $7.5 \times 9.8 \mathrm{~cm}$, and their consistent form: each is of sufficient thickness (approximately $15 \mathrm{~mm}$ ) to have enabled the carving of a deep groove along the underside of the bottom edge to facilitate insertion into a base, and is rebated along the top edge to enable the secure closure of a lid. Visible traces of a lock on the crucifixion relief and hinges on the third relief in the series (which would thus have been the back of the casket), remain. Hence the ivories present episodes that would have been viewed in narrative order around a box small enough to have been handled by an individual.

Ivory boxes fulfilled a variety of functions in the ancient world-as containers of medicine, as well as jewellery and, with the rise of the cult of relics in the fourth century, as containers of sanctified matter connected to the life of 
Christian martyrs. That such objects were susceptible to damage and destruction is witnessed not only in the low numbers of ivory boxes to survive intact, but also by the state of preservation of those that do. Aside from the obvious fact that the Maskell Passion ivories are now detached from the object of which they were structurally a key part, on the crucifixion panel alone we can observe the breakage and subsequent loss of such features as the soldier's spear and the trunk of the tree (which has been repaired), as well as smaller details such as various fingers from Jesus' hands.

Only two complete ivory caskets decorated with Christian imagery of similar date survive for comparison with the Maskell panels. The Brescia Casket, discussed above, is the earlier of the two, dating to the late fourth century and possibly of Northern Italian origin. Aside from the notably large range of Old and New Testament images with which it is decorated, it features a detailed Passion cycle illustrated prominently on its lid. Although this cycle ends before the crucifixion, and so does not include a depiction of Jesus' own death scene, the deaths of other biblical figures are included: as has already been mentioned, a range of popular scenes illustrating biblical characters delivered from death are featured, and a small representation of the suicide of Judas appears on the rear (Figure 5).

The second, later example is the so-called Pola Casket, made in Rome between 440 and 450. It is decorated with a variety of Christian images including an interior view of St Peter's Basilica in Rome, showing the shrine built there to mark the site of Peter's tomb. ${ }^{33}$ The increasing interest in Rome at the turn of the century in the activities of Peter and Paul, and so in the primacy of the church in that city, is further witnessed on the lid of this casket where Jesus is depicted handing a scroll to Peter with a gesture often attributed in ivory consular diptychs to emperors passing an imperial decree to a minister. The act symbolises the handing over of the new Christian law, superseding that of the Old Testament, directly to Peter. ${ }^{34}$

The carefully decorated lids of the Brescia and Pola caskets make even more likely the theory that the Maskell Passion series originally included a lid decorated with a fifth subject to complete the Passion narrative. ${ }^{35}$ Moreover, as Elsner recently emphasised, such boxes were small enough to be handled by a single person, so that the chief face to be viewed was not the front but the top, the lid. ${ }^{36}$ The hypothetical 
inclusion of a final scene is important when we come shortly to consider the overall theme of the Maskell Passion Ivories.

The function of these caskets remains difficult to reconstruct with certainty, although they are often thought to have been used as repositories for sacred relics. Such a hypothesis is attractive, given the known circulation of relics at this period in the history of the church, and the later popularity of ivory in the manufacture of reliquaries. ${ }^{37}$ Yet other possibilities should be considered. The specific theme selected for the Maskell Passion series for instance, coupled with the high quality of carving (which suggests that it was commissioned by a wealthy patron), could indicate that the casket was made to house a holy relic relating to Jesus' death and resurrection, or that it functioned as a portable container for a portion of the consecrated Eucharist.

If we turn now to examine this object in detail, it will be possible to understand more fully the broader narrative context into which the scene of Jesus' death is placed; in this process, we will also be able to appreciate more acutely the dexterity of the artist in selecting specific episodes, consciously arranging the action of each within defined spatial parameters, and in linking those episodes-thereby creating for the viewer a powerful sense of unfolding historical drama.

\section{-NARRATIVE CONTEXT}

The account of Jesus' Passion as it is illustrated across the Maskell Ivories begins on the first panel in the series, where three episodes are illustrated so as to be read in sequence, from left to right-as ancient Roman viewers were accustomed to do, for both images and texts. ${ }^{38}$ The opening episode is that of Pilate washing his hands of the decision to crucify Jesus (Matthew 27:24). The second episode is Jesus carrying his own cross (John 19:17). The third is of Peter denying Jesus, following most closely the version in John 18:17-18, where the disciple warms himself before the charcoal fire and is questioned by a maidservant.

The artist's skill in carving in this medium enables illustration of several pictorial elements within each of the three narrative episodes (the cock, the maidservant, and Peter's own gesture, for example, in the final episode) and so evoke both the fuller text and wider significance of each event. One might expect that across such a small surface area, the composition becomes congested by these 
details; yet moving swiftly and dramatically through the initial phases of Jesus' Passion, the artist has utilised the spatial constrictions cleverly, so that both narrative and pictorial coherence is maintained across the panel as a whole. The inclusion of an incident relating to Peter is significant. While this episode is concordant with the interest during this period in the mission of the Apostles, as noted above in the case of the Pola Casket and the series of Apostle Ivories (Figure 4), it also functions to set up a powerful visual and theological contrast with the depiction of Judas on the next panel. The speed with which the first panel is thus able to take us through Jesus' arrest is also a critical means of enabling the drama of the next panel to operate with maximum impact.

Across the second relief, only two episodes are depicted. First is the suicide of Judas (Matthew 27:3-5), continuing the theme of betrayal with which the first panel ended; and second is the crucifixion of Jesus. As discussed above in relation to the Brescia Casket, both Peter and Judas betrayed Jesus; yet while Peter repented and became the heir to Jesus' power, his ministry and his headship of the Church, Judas despaired and hanged himself. ${ }^{39}$ On the first panel, Peter is shown in a dynamic, open posture-one of brash discourse, perhaps; the figure of Judas by comparison is one of intense and tragic introspection. As the first episode on the second relief, he is shown hanging from a tree at the far left of the panel, limbs falling lifelessly in what is an exceptional illustration of suicide by hanging in the ancient world, and an extraordinary Christian portrayal of death. The earlier Brescia Casket preserves an almost identical image of Judas (Figure 5), indicating that although this subject was utilised only rarely at this period, it was known before the carver of the Maskell Ivories came to depict it. Yet in this context, juxtaposed at one remove with Peter's denial on the previous panel and with Jesus' death in the same frame, the image assumes a different level of intensity, and so of importance. Despite this, the more prominent figure on the second relief is that of Jesus, nailed high up on the cross, flanked by his mother and John on one side (John 19:25-27) and a soldier on the other (John 19:34-35).

Mary and John are shown walking towards the cross in stock postures of mourning, familiar from Graeco-Roman funerary art. With their eyes downcast, they lead us forward to the figure of Jesus, whose eyes are wide open and stare with intensity - a factor helping to draw the visual centre of this composition to his body. 
He is shown in rigid frontality, as though standing defiantly against the cross and voluntarily unfolding his arms flat against the cross-beam, his hands stretched out and unflinching at the nails penetrating the palms. Jesus is also unmoved by the action of the Roman soldier-who is shown lunging into the foreground at the far right of the panel in order to plunge the lance into Jesus' left side. The posture can be readily compared with classical models in funerary art for the depiction of mythical heroes enacting deeds of violence. In this context of course, as the viewer would recognise, the deed is futile and the hero is not the perpetrator but the recipient of the piercing. A nimbus encircles Jesus' head, as it does again in the fourth panel, pointing to the fact that his indomitable divinity is shown forth on the cross and further revealed in the resurrection.

After the narrative pace of the first two panels has thus built to a crescendo with the crucifixion, the following panel pulls the viewer to an abrupt halt. The third relief in the series depicts just one scene: the women who gathered at the tomb of Jesus and bore witness to his resurrection (Matthew 28:1-7; Mark 16:1-8; Luke 24:1-8). The active gestures that characterise the first two panels are gone; in their place are figures that in starkly different ways are profoundly composed and still. At the centre of the relief, the eye is drawn to the empty tomb. Two grieving women are shown seated, wrapped tightly in their shawls and hunched over, turning in on themselves in stock poses of sorrow taken from Roman funerary art. They are placed either side of the tomb, facing inwards and thus contrasted with the pair of sleeping soldiers in the foreground, who also face inward but lean away from the tomb, sprawled lazily on their shields and lances. The doors of the tomb are ajar, one having burst open and splintered. An empty sarcophagus, decorated in a style common in Rome in earlier centuries, is glimpsed inside. The doors themselves are decorated with carved panels, in the manner of some finely carved wood doors on contemporary churches in Rome. One of these clearly depicts the resurrection of Lazarus, serving as a reference to Christ's own resurrection; another panel exactly replicates the posture of one of the women, seated in mourning.

While the third relief has alluded to the resurrection of Jesus from the dead, even taking us inside the empty tomb, the fourth and final surviving panel in the series boldly trumpets the fact of his resurrection with an energetic representation of the risen Jesus appearing before and interacting with his disciples. Jesus is 
depicted fully clothed, standing on a podium, flanked by two disciples on either side. He strikes the classical gesture of discourse with his left arm thrust vigorously into the air, the palm open. ${ }^{40}$ In this context, the rhetorical gesture-taken from Roman art, where it was used to denote a philosopher, teacher or even politician-is inventively exploited to reveal the wound in Jesus' side to the diminutive figure of the sceptical Thomas below, who inserts his pointed fingers into the wound in wonder (John 20:24-28). This latter act ensures that we are in no doubt about the identity of the central figure: this is the crucified Jesus, raised from the dead. The gesture also evokes that noted above on the lid of the Pola Casket, where Jesus symbolically hands the law to Peter and thus entrusts him with the mission of the Church. Hence this scene is also evocative of Matthew 28:16-20, where Christ commissioned the apostles to go forth and teach and baptise in his name.

Although it is possible that the lid was also decorated to include a further scene, one that might have consolidated further the theme of triumph, there is enough evidence from the four panels to suggest that even though individually they relate specific narrative details from different gospel accounts of the Passion, the concern of the sequence as a whole lies beyond the literal depiction of these details, beyond even the historical occurrence of Jesus' death. Taken together, the unified focus of the final two panels, on the resurrection and Jesus' sending out of the apostles to continue his work, bears witness to the fact that the series in its entirety is specifically concerned with Jesus' triumph over death in the resurrection, and of the subsequent triumph of the Church. The two actual scenes of death-the suicide of Judas and the Crucifixion of Jesus-are pivotal in the articulation of both thematic strands.

Despite the remarkable character of these two images, the Maskell Passion Ivories thus continue and build on a solid early Christian thematic emphasis in art, rather than presenting a radical departure from it. Hence while the Crucifixion as it is illustrated within the narrative across the Maskell Ivories might survive as a very rare example of the literal pictorialisation of the death of Jesus in the early Christian period, it also continues the early Christian focus on hope in resurrection to eternal life, offering a more explicit exploration of this theme. Hence, if we look at what other scenes of death were (or were not) depicted prior to the fifth century, it is possible to appreciate the way in which the scene of Jesus' death entered Christian 
narrative art not simply as a means of enunciating the fact of his death, but as a means of pointing to broader historical and theological realities: the triumph of the church, and the hope of Resurrection to eternal life that membership of Christ's church offered.

\section{-SOME CONCLUSIONS}

The Maskell Passion Ivories are an important example of the superior standard of carving achieved in Rome in the early fifth century, including the sophistication of their design-with highly complex pictorial compositions preserving a visual narrative of Jesus' Passion that is unprecedented in its detail. Yet in addition to reflecting the skill of this carver, the very fact of the meticulous details-from the careful individualisation of faces, to the inclusion of such small pictorial elements as the tiny coin purse beneath the feet of Judas and the nest of birds in the tree from which he hangs-also suggest the artist was working from a pictorial narrative tradition of the Passion that was already highly evolved. In other words, although the series includes the earliest known depiction of the crucifixion in a narrative context, it is probably not the first time that such a depiction was attempted.

In extant pictorial narratives from the early Christian period, images depicting the event of the crucifixion are scarce. Given the thematic and artistic background to the production of ivories, we might expect a reticence to explicitly portray Jesus' death. Moreover, given the tradition of using post-death scenes as examples of salvation, one could anticipate that even if the Jesus' death scene was to be represented literally, the resurrection would be the part of the broader story emphasised-the victory, and not the death itself, death effectively 'swallowed up in the victory' (1 Corinthians 15:54).

And this is indeed what we find in the Maskell crucifixion scene, not simply in the dominance of the resurrection in the narrative as a whole, but even in the very depiction of Jesus already triumphant on his cross-commanding the viewer's attention with his eyes wide open, limbs pulsating with energy, head held firmly erect and gazing directly out of the image, less a picture of death than an image of life. 
Felicity Harley McGowan is an art historian with specific interest in the material culture of late antique Rome. She is currently the Gerry Higgins Lecturer in Medieval Art History at the University of Melbourne.

-NOTES

I am particularly grateful to Bruce Buchan for the invitation to participate in the highly innovative and inspiring interdisciplinary symposium that was The Death Scene: Perspectives on Mortality, in July 2009. My thanks are due to the organisers, David Ellison, Margaret Gibson and Bruce, who have since provided invaluable support and input regarding the content of my essay as it is presented here; to Lachlan Turnbull and the two anonymous readers for their suggestions; and to Andrew McGowan for his comments, corrections and constancy. I offer this paper in memory of George.

${ }_{1}$ Matthew 27:37; Mark 15:26; Luke 23:38; John 19:19-22.

2 Matthew 27:33-44; Mark 15:22-32; Luke 23:33-43; John 19:17-30.

${ }^{3}$ Contrasting Kurt Weitzmann, who argued that illustrations were physically bound to the text on which they were based, Penny Small has proposed that pictures produced by ancient artists reflect oral traditions rather than texts, Jocelyn Penny Small, The Parallel Worlds of Classical Art and Text,

Cambridge University Press, Cambridge, 2003, passim and p. 2. A useful and concise introduction to art historical discussions of visual narrative in Western art remains that of Marilyn Aronberg Lavin, The Place of Narrative. Mural Decoration in Italian Churches, 431-1600, University of Chicago Press, Chicago and London, 1990, pp. 1-3.

4 The Maskell Passion Ivories (including the iconography of Judas' suicide and Jesus' crucifixion preserved thereon) form the focus of a more detailed study by the author, the publication of which is forthcoming.

${ }^{5}$ For the treatment of Roman art as a visual language, see Tonio Hölscher, The Language of Images in Roman Art, trans. A. Snodgrass and A. Künzl-Snodgrass, Cambridge University Press, Cambridge, 2004, including the critical comments of Jaś Elsner in the Foreword, pp. xv-xxxi.

${ }^{6}$ On the importance of artistic developments across the third century, see Paul Corby Finney, The Invisible God, Oxford University Press, Oxford, 1997, especially pp. 90 ff.

${ }^{7}$ For essays on this topic, see the collection in Sheila Dillon and Katherine Welch (eds), Representations of War in Ancient Rome, Cambridge University Press, Cambridge, 2006. 
8 Jeffrey Spier (ed.), Picturing the Bible: The Earliest Christian Art, New Haven, Yale University Press, 2007, pp. 1-23, especially pp. 4-6; and Mary Charles Murray, 'The Emergence of Christian Art', in Spier (ed.), pp. 51-63.

${ }^{9}$ The work of Mary Charles Murray has been pivotal in demonstrating the degree to which the hostility on the part of the early Church fathers was exaggerated by modern scholars: Rebirth and Afterlife: A Study of the Transmutation of Some Pagan Imagery in Early Christian Funerary Art, British Archaeological Reports (International Series 100), Oxford, 1981, especially pp. 1-36.

10 The question was raised, but not really solved, by André Grabar in his monograph, Christian Iconography: A Study of its Origins, London, Routledge, 1969. See now Finney, ch. 5.

11 Most Christians lived in what Ramsey MacMullen refers to as the 'suburbs': The Second Church. Popular Christianity A.D. 200-400, Atlanta, Society of Biblical Literature, 2009, pp. 23-32, and conclusions across pp. 104-11.

12 Robin Jensen, Understanding Early Christian Art, Routledge, London and New York, 2001, pp. 20-1, gives a clear summary of the context and setting of the earliest Christian art such as is known from material evidence. The breadth of material evidence-beyond funerary art-is now most comprehensively documented in Spier (ed.), passim.

13 See Jaś Elsner, Imperial Rome and Christian Triumph, Oxford University Press, Oxford and New York, 1998, chapter 6: 'Art and Death', and Everett Ferguson, Backgrounds of Early Christianity, W.B.

Eerdmans, Grand Rapids, Michigan, 1993, 'Death and the Afterlife', pp. 243-52 (with bibliography). The classic work on death in ancient Rome, which includes some reference to Christian practice, remains Jocelyn M. C. Toynbee, Death and Burial in the Roman World, London, Thames \& Hudson, 1971. See now also: Catharine Edwards, Death in Ancient Rome, Yale University Press, New Haven and London, 2007 and Maureen Carroll, Spirits of the Dead: Roman Funerary Commemoration in Western Europe, Oxford University Press, Oxford, 2006. For a recent and useful analysis of narratives of Roman funerary ritual in a selection of literary texts see Mario Erasmo, Reading Death in Ancient Rome, Ohio State University Press, Columbus, 2008; and on death scenes as sites of public display/entertainment, Donald G. Kyle, Spectacles of Death in Ancient Rome, Routledge, London and New York, 1998.

14 Éric Rebillard has insisted upon the non-involvement of the Church in what (he argues) remained essentially private, family matters, with the early Christians maintaining the prevailing local traditions: 'The Church, the Living, and the Dead', in Philip Rousseau (ed.), A Companion to Late Antiquity, WileyBlackwell, Chichester, 2009, pp. 220-30, including a brief bibliography.

15 The literature is comprehensive. Franz Cumont's study remains seminal: Recherches sur le symbolisme funéraire des Romains, Paul Geuthner, Paris, 1942. Recent studies include: Michael Koortbojian, Myth, Meaning and Memory on Roman Sarcophagi, University of California Press, Berkeley and Los Angeles, 1995; and Glenys Davies, 'Roman Funerary Symbolism in the Early Empire', in J.B. Wilkins and E. Herring (eds), Inhabiting Symbols: Symbol and Image in the Ancient Mediterranean, Accordia Research Institute, University of London, London, 2003, pp. 211-27. Regarding the trend 
towards symbolic decoration on sarcophagi by the middle Antonine period, Natalie Boymel Kampen, 'Biographical Narration and Roman Funerary Art', American Journal of Archaeology, vol. 85, no. 1, 1981, pp. 47-58. On the use of Greek mythology on sarcophagi in the Roman funerary context, Genevieve Gessert, 'Myth as Consolatio: Medea on Roman Sarcophagi', Greece and Rome, second series, vol. 51, no. 2, 2004, pp. 217-49.

16 On Christian death and burial, and usage of the catacombs, in Rome see the recent comments of MacMullen, pp. 69-76.

17 Concerning the nature of early Christian art, Jensen gives a concise summary, pp. 10-12.

18 The text is cited in Fernand Cabrol and Henri Leclercq, Dictionnaire d'archéologie chrétienne et de liturgie, Letouzey et Ané, Paris, 1907-1953, vol. 14, no. 1, columns 435-36. See the excellent discussion by Catherine Brown Tkacz, The Key to the Brescia Casket: Typology and the Early Christian Imagination, University of Notre Dame Press, Paris, 2001, pp. 109-37, with references to previous research on the prayer.

19 Engraved bowl with biblical scenes, found at Podgoritza, Montenegro, fourth century. Glass, State Hermitage Museum, Saint Petersburg. Spier (ed.), p. 9, fig. 4.

20 There is a fuller discussion in Spier (ed.), pp. 8-10, and fig. 4.

${ }^{21}$ On the iconography of Daniel in early Christian art: M. Minasi, 'Daniele', in Fabrizio Bisconti (ed.), Temi di iconografia paleocristiana, Vatican City, 2000, pp. 162-4.

22 The Brescia Casket, c. 390 AD, Museo Cristiano, Brescia. Tkacz's monograph on the casket is the most recent detailed study.

${ }^{23}$ Jaś Elsner, 'Framing the Objects we Study: Three Boxes from Late Roman Italy', Journal of the Courtauld and Warburg Institutes, vol. 71, 2008, p. 24.

24 This is, therefore, a fine example of classical form (the poses and gestures of mourning women) being taken up from mythological representations and utilized in a Christian pictorial context for the representation of Christian story. On the impact of mythological on Christian scenes a classic study remains Kurt Weitzman, 'The Survival of Mythological Representations in Early Christian and Byzantine Art and their Impact on Christian Iconography', Dumbarton Oaks Papers, vol. 14, 1960, passim. However, on the specific representation of women in distress or mourning and the influence on early Christian art see Nurith Kenaan-Kedar, 'The New Images of Women in Early Christian Art', Assaph vol. 2, 1996, pp. 83-92.

25 Spier (ed.), cat. no. 60. British Museum, MME 1856.06-23.8-10.

${ }^{26}$ Herbert Kessler, 'Scenes from the Acts of the Apostles on Some Early Christian Ivories', Gesta, vol. 18, no. 1,1979, p. 12.

${ }^{27}$ A subject that also appears on contemporary sarcophagi: Kessler, fig. 3.

28 Tkacz, p. 223.

${ }^{29}$ For the evidence: F. Harley in Spier (ed.), cat. nos 55-7, pp. 229-32. 
30 This evidence includes the well-known graffito excavated on the Palatine Hill, Rome, which appears to parody Christian belief in a crucified deity: further on this evidence see M. Itkonen-Kaila and H. Solin in V. Väänänen (ed.), Graffiti del Palatino vol. 1: Paedagogia, Acta Instituti Romani Finlandiae 3,

Helsinki, 1966, pp. 40-1, fig. 35 and pp. 209-12, no. 246.

${ }^{31}$ Further on the ivories, see the catalogue entry (with short bibliography) by F. Harley in Spier (ed.), cat. 57, pp. 229-32.

32 Consuls were the administrators of the capital cities in the Roman Empire. The earliest known consular diptych is that made for Probus in 406. On ivory carving at this date, see Bente Kiilerich, Late Fourth Century Classicism in the Plastic Arts: Studies in the So-called Theodosian Renaissance, Odense University Press, Odense, Denmark, 1993.

33 The ivory Pola Casket, Museo Archeologico, Venice, c. 450?. The exact date is disputed. Davide Longhi, La capsella eburnean di Samagher: iconografia e committenza, Edizioni del Girasole, Ravenna, 2006.

34 On this iconographic type, known as the traditio legis ('giving of the law'), its use and development in the fourth century in early Christian art, see briefly Robin Jensen, Understanding Early Christian Art, Routledge, London, 2000, pp. 97-100, and in more detail Bas Snelders, 'The Traditio Legis on Early Christian Sarcophagi', Antiquité Tardive, vol. 13, 2005, pp. 321-33.

35 Frederick Gerke hypothesised that on the missing casket lid one might expect to see a depiction of the ascension. He pointed out that this subject appears within the cycle of Old and New Testament scenes depicted on the fifth century doors of the Church of Santa Sabina but, perhaps most critically, it is the conclusion to the Passion cycle on the so-called Servannes Sarcophagus (produced in a Roman workshop around the second third of the fourth century) or a scene of Jesus as ruler of the universe (such a Maiestas Domini, or perhaps the traditio legis as appears on the lid of the Pola Casket): 'Die Zeitbestimmung der Passionssarkophage', Archaeologiai ertesito, vol. 52, 1940, p. 46.

36 Elsner, p. 31.

37 On the process whereby human body-parts became relics in late ancient Christianity, and the critical role of art in the cultural expression of devotion towards these objects: Patricia Cox Millar, "'The Little Blue Flower Is Red": Relics and the Poetizing of the Body', Journal of Early Christian Studies, vol. 8, no. 2, 2000, pp. 213-36.

38 See Koortbojian, p. 44.

${ }^{39}$ As Tkacz describes, this contrast is set up first on the Brescia Casket, p. 104.

${ }^{40}$ Compare the iconography with a late second century grave relief from Ostia where a philosopher stands on a similar podium, elevated above his audience, with one arm raised and the other at his side. According to Paul Zanker, it is the upturned gaze and solemn gesture that indicate this figure is a philosopher: The Mask of Socrates: The Image of the Intellectual in Antiquity, trans. Alan Shapiro, University of California Press, Berkeley and Los Angeles, 1995, p. 260 and fig. 140, p. 261. 